\title{
Editorial: Rationality and Politics
}

In the near universal dismay among 'thinking' Europeans at the reelection of President George W. Bush there has been one un-thinking notion which has reached cliché status so often has it been repeated.

It is that what we saw in America on November 2nd was a manifestation, among 60 million Americans or so, of pre-Enlightened irrationality. Bush, this view has it, was elected by the religious right which, by definition, is anti-science. Ruling the roost in the world's only remaining super-power it is, almost by definition, dangerous. It is dangerously dogmatic in its opposition in principle to the progress made in moral matters by secularism over the past century or two, and dangerous in that it is a view which now has so much power behind it.

There certainly are minds of distinction opposed to pretty well everything the present American administration stands for. In the field of foreign policy, one such is Noam Chomsky, whose impassioned address given as the Royal Institute of Philosophy's annual lecture for 2004 appears in this issue of Philosophy. There are minds of distinction thoroughly committed to ethical consequentialism and others to the conclusion that neo-Darwinian evolution is as close to the fullness of truth as a scientific theory could ever be. Some of these minds, too, have appeared and will continue to appear in the pages of Philosophy. They, as Chomsky, should certainly be listened to with respect and studied carefully. It is also true that in Europe in education and in the public sphere more generally one would not be encouraged to promote the views on sexual morality or on climate change or on the theory of evolution which are supposedly so widespread among Bush supporters. But that fact is not quite the ringing endorsement of European rationality it might seem to be.

Before we accede to the conclusion that America, or at least middle America, is truly another country cut off altogether from rational discourse and by its own stupidity cast out of the republic of letters, maybe we should ask ourselves whether there might not actually be something a little isolationist, even dogmatic about this easy assumption of intellectual and rational superiority. Many of the issues which divide the 'two' American nations we hear so much about these days and which separate 'religious' America from 'secular' Europe are complicated, for all the brilliance of those arguing doi:10.1017/S003181910500001X

(C)2005 The Royal Institute of Philosophy

Philosophy 802005 


\section{Editorial}

the 'secularist' case. (Any brilliance on the other side tends to go unnoticed.) In the current state of discourse, some of these issues may be undecidable on purely rational grounds. And this may partly explain why they tend to arouse so much passion and get turned into political causes and treated as political rather than as intellectualon both sides.

Those who make too quick an assumption that reason is all on their side, and prejudice only on the other, may at the very least be foreclosing the development of their own rationality by stereotyping those with views other than their own as bigots from another world with whom rational discourse is just not possible. 